\title{
Editorial
}

Journal of Innate

Immunity

Published online: July 5, 2010

DOI: $\underline{10.1159 / 000318190}$

\section{Systemic Inflammatory Response Syndrome and Compensatory Anti-Inflammatory Response Syndrome in Sepsis}

\author{
Tom van der Poll Joost C.M. Meijers \\ Center of Experimental and Molecular Medicine, Center of Infection and Immunity, and Departments of \\ Vascular Medicine and Experimental Vascular Medicine, Academic Medical Center, University of Amsterdam, \\ Amsterdam, The Netherlands
}

In 1991, the American College of Chest Physicians (ACCP) and the Society of Critical Care Medicine (SCCM) convened a consensus meeting to define the systemic inflammation that was recognized to accompany severe infection and sterile trauma. A year later, the ACCP/SCCM Consensus Conference introduced the term 'systemic inflammatory response syndrome' or SIRS in its meeting report [1]. SIRS was (and still is) considered to be present when patients have 2 or more of the following clinical findings: body temperature $>38^{\circ} \mathrm{C}$ or $<36^{\circ} \mathrm{C}$; heart rate $>90 / \mathrm{min}$; hyperventilation evidenced by a respiratory rate of $>20 / \mathrm{min}$ or a $\mathrm{PaCO}_{2}$ of $<32 \mathrm{~mm} \mathrm{Hg}$, and a white blood cell count of $>12,000$ cells $/ \mu l$ or $<4,000$ cells/ $\mu l$. It was appreciated that SIRS could be the consequence of different underlying conditions, including infection, trauma and other types of sterile injury. Since then, sepsis is defined as documented or suspected infection with evidence of systemic inflammation, consisting of 2 or more SIRS criteria. In 1996, Roger Bone (1941-1997), who had been the chair of the ACCP/SCCM Consensus Conference, introduced a second acronym to portray the host response during sepsis, CARS or 'compensatory anti-inflammatory response syndrome', seeking to describe an immunological phenomenon that was increasingly noticed to occur in sepsis, characterized by the induction of several anti-inflammatory mechanisms [2]. Nowadays, the concepts of SIRS and CARS still exist, although the notion that CARS represents a reaction to SIRS has been challenged $[3,4]$.

In this theme issue of the Journal of Innate Immunity, current knowledge of several aspects of the SIRS and CARS concepts are reviewed in 7 articles; the issue is completed by 3 original articles about these topics. Kumpf and Schumann [5] summarize data on genetic variations in Toll-like receptors and cytokines (important components of the host response to sepsis) and their impact on the course of severe infection. These authors also analyzed evidence coming from animal experiments showing that adequate triggering of Toll-like receptors and cytokine production are needed for containment of infections. McCall and colleagues [6] discuss the role of epigenetic processes of innate immune cells (i.e. changes in the phenotype or gene expression caused by mechanisms other than changes in the underlying DNA sequence) during infection accompanied by SIRS, describing the host response in 4 stages: homeostasis, incitement, evolution and resolution. Coll and O'Neill [7] contribute with an extensive overview of the role of Tolllike receptors and Nod-like receptors in the induction of an innate immune response to pathogens. In addition, they discuss negative regulators of these pathways, which on the one hand seek to dampen excessive inflammation

\section{KARGER}

Fax +41613061234

E-Mail karger@karger.ch

www.karger.com
(C) 2010 S. Karger AG, Basel

$1662-811 X / 10 / 0025-0379 \$ 26.00 / 0$

Accessible online at:

www.karger.com/jin
Dr. Tom van der Poll

Academic Medical Center, University of Amsterdam

Meibergdreef 9, Room G2-130

NL-1105 AZ Amsterdam (The Netherlands)

Tel. +31 20566 5910, Fax +31 20697 7192, E-Mail t.vanderpoll@amc.uva.nl 
but on the other hand can cause immune suppression. de Jong and colleagues [8] provide an overview of different inflammatory and procoagulant cascades that become activated during severe sepsis, each of which may contribute to the occurrence of organ failure in an overwhelming SIRS. Linder and colleagues [9] write about heparin-binding protein, a multifunctional granuleassociated protein in polymorphonuclear leukocytes, which can activate monocytes and macrophages and can induce vascular leakage and edema formation. They discuss the potential value of heparin-binding protein as a diagnostic marker and a target for treatment. Ward [10] describes the evidence that robust activation of the complement system occurs as part of sepsis-associated SIRS. Focusing on the complement activation product $\mathrm{C} 5 \mathrm{a}$, he proposes that interception of $\mathrm{C} 5 \mathrm{a}$ in sepsis may preserve innate immune functions and may represent an attrac- tive approach to treat sepsis. Russell and Walley [11] focus on the effects of vasopressin, a stress hormone that has been used to increase blood pressure during septic shock, on immune functions such as altering cytokines, prostaglandins, humoral immunity and immune cells. Three original articles, describing gene expression levels of apoptosis regulators [12], activity of lymphocyte subpopulations [13] and the plasma levels of antimicrobial peptides [14] in clinical or experimental sepsis, total this theme issue.

Sepsis remains a major challenge for clinicians and scientists. SIRS and CARS attempt to describe the complex nature of the host response to a severe infection or trauma. With this theme issue, the reader will become up to date with regard to several topics in this field. As guest editors we wish you as much pleasure in reading this issue as we had in putting it together!

\section{References}

$\checkmark 1$ Bone RC, Sibbald WJ, Sprung CL: The ACCP-SCCM consensus conference on sepsis and organ failure. Chest 1992;101:14811483.

$>2$ Bone RC: Immunologic dissonance: a continuing evolution in our understanding of the systemic inflammatory response syndrome (SIRS) and the multiple organ dysfunction syndrome (MODS). Ann Intern Med 1996;125:680-687.

$\checkmark 3$ Munford RS, Pugin J: Normal responses to injury prevent systemic inflammation and can be immunosuppressive. Am J Respir Crit Care Med 2001;163:316-321.

$\checkmark 4$ Hotchkiss RS, Karl IE: The pathophysiology and treatment of sepsis. N Engl J Med 2003; 348:138-150

$>5$ Kumpf O, Schumann RR: Genetic variation in innate immunity pathways and their potential contribution to the SIRS/CARS debate - evidence from human studies and animal models. J Innate Immun 2010;2:381394.
6 McCall CE, Yoza BK, Liu T, El Gazzar MA: Gene-specific epigenetic regulation in serious infections with systemic inflammation. J Innate Immun 2010;2:395-405.

7 Coll RC, O’Neill LAJ: New insights into the regulation of signalling by Toll-like receptors and Nod-like receptors. J Innate Immun 2010;2:406-421.

$>8$ de Jong HK, Van der Poll T, Wiersinga WJ: The systemic proinflammatory response in sepsis. J Innate Immun 2010;2:422-430.

$>9$ Linder A, Soehnlein O, Åkesson P: The role of heparin-binding protein in bacterial infections. J Innate Immun 2010;2:431-438.

10 Ward PA: The harmful role of C5a on innate immunity in sepsis. J Innate Immun 2010; 2:439-445.
11 Russell JA, Walley KR: Vasopressin in septic shock including immune effects. J Innate Immun 2010;2:446-460.

$\checkmark 12$ Hoogerwerf JJ, van Zoelen MA, Wiersinga WJ, van't Veer C, de Vos AF, de Boer A, Schultz MJ, Hooibrink B, de Jonge E, van der Poll T: Gene expression profiling of apoptosis regulators in patients with sepsis. J Innate Immun 2010;2:461-468.

13 Zeckey C, Hildebrand F, Hoevel P, Mueller K, Krettek C, Barkhausen T, van Griensven $\mathrm{M}$ : Activity of lymphocyte subpopulations in polymicrobial sepsis and DHEA treatment in IL- 6 knockout mice. J Innate Immun 2010;2:469-477.

14 Berkestedt I, Herwald H, Ljunggren L, Nelson A, Bodelsson M: Plasma levels of antimicrobial polypeptides in patients with severe sepsis. J Innate Immun 2010;2:478-482. 